\title{
On Contested Shores: The Evolving Role of Amphibious Operations in the History of Warfare. Edited by Timothy Heck and B.A. Friedman. Quantico, VA: Marine Corps University Press, 2020.
}

John P. Sullivan

Hal Kempfer

Follow this and additional works at: https://digitalcommons.usf.edu/jss

pp. $116-127$

\section{Recommended Citation}

Sullivan, John P. and Kempfer, Hal. "On Contested Shores: The Evolving Role of Amphibious Operations in the History of Warfare. Edited by Timothy Heck and B.A. Friedman. Quantico, VA: Marine Corps University Press, 2020.." Journal of Strategic Security 14, no. 4 (2021) : 116-127.

DOI: https://doi.org/10.5038/1944-0472.14.4.1994

Available at: https://digitalcommons.usf.edu/jss/vol14/iss4/10

This Book Review is brought to you for free and open access by the Open Access Journals at Digital Commons @ University of South Florida. It has been accepted for inclusion in Journal of Strategic Security by an authorized editor of Digital Commons @ University of South Florida. For more information, please contact digitalcommons@usf.edu. 


\section{On Contested Shores: The Evolving Role of Amphibious Operations in the History of Warfare. Edited by Timothy Heck and B.A. Friedman. Quantico, VA: Marine Corps University Press, 2020.}




\section{On Contested Shores: The Evolving Role of Amphibious Operations in the History of Warfare. Edited by Timothy Heck and B.A. Friedman. Quantico, VA: Marine Corps University Press, 2020. ISBN 9781732003149 (paperback). 452 pages.}

Review Essay by John P. Sullivan and Hal Kempfer

Amphibious operations have been a significant component of warfare since classical times. Much of the world relies upon maritime connections or sea lines of communications, and maritime forces have long been used to project power and ensure security. As we write this two of the world's major powers the United States and the United Kingdom are renewing the amphibious focus of the marine forces: the United States Marine Corps ${ }^{1}$ and Royal Marine Commandos ${ }^{2}$ while China's People's Liberation Army Navy (PLAN) is building amphibious capabilities to assert Chinese hegemony throughout the South China Sea and beyond. 3

On Contested Shores: The Evolving Role of Amphibious Operations in the History of Warfare looks at the significance of amphibious operations over time and points to their continued relevance in the future. It is edited by Timothy Heck, an artillery officer with an MA in war studies from King's College, London and B.A. Friedman, a U.S. Marine Corps Reserve officer with an MA in national security and strategic studies from the U.S. Naval War College in Newport, Rhode Island. They start the inquiry into amphibious warfare in their introduction stating, "The projection of power from the sea, be it for conquest or humanitarian assistance, remains a core task for militaries worldwide" (p. 3).

They note that for most casual observers-and many historians and strategists-amphibious operations are viewed through the lens of Gallipoli, Tarawa, or Normandy (p. 3). Indeed D-Day, the Normandy Landings or Operation Overlord, starting 6 June 1944 epitomizes amphibious warfare. Yet, for many the complex integration of naval forces seen in Operation Neptune (the naval preparation and operations that enabled the landings) are overtaken by images of the airborne and amphibious assaults by U.S. forces at Utah and Omaha Beach, British forces at Sword and Gold, and Canadians at Juno. For U.S. Marines, the 
Pacific campaign characterized by amphibious assaults at Guadalcanal and Iwo Jima-among many others during the island-hopping campaignsresonate. 4

The text contains a forward by Brigadier General Jason Q. Bohm, USMC, a preface by the editors, a glossary of terms and acronyms, and the editors' introduction which charts the course for the exploration of amphibious operations over time. Here the editors specify that there are currently five types of amphibious operations in U.S. doctrine. These are the assault, the withdrawal, the raid, the demonstration, and finally amphibious support to other operations (p. 5). The assault as previously mentioned dominates the conceptual landscape. As the text amply asserts that has not been and will not be the only focus of amphibious operations in the future.

On Contested Shores describes the application (and utility) of these various types of amphibious operations in twenty-three chapters, followed by a short conclusion by Heck and Friedman. The text includes seventyfive figures (images, map, and charts) that help bring context to the case studies discussed, and a listing of selected readings on amphibious operations. While amphibious operations are expected to continue in relevance-albeit in updated and morphed form-it has been a longstanding tradition to claim they are obsolete. The editors recount General Omar Bradley's 1949 forecast that there would never be another largescale amphibious operation by reminding us that American forces defied that projection and landed at Inchon, South Korea in less than a year (p. 6). 5

\section{Case Studies: Chapters One-Nine}

Chapters One-Nine span the period from the late $16^{\text {th }}$ Century (1555) to the Gallipoli Campaign during World War I in the early 20th (1915-1916). First, Jacopo Pessina, an Italian scholar, looks at an amphibious special operation in Tuscany on 2 June 1555 in Chapter One. Here a Florentine force conducted a night assault against a French-Sienese garrison at Porto Ercole, Tuscany. The operation confirms the importance of information collection (what we now call geospatial intelligence) and espionage in mission planning (p. 23). Ultimately, the assault's success was ensured through surprise and the use of "skilled skirmishers" (p. 24). 
In Chapter Two, Samuel de Korte, at Utrecht University, examines the 1575 Siege of Leiden. This engagement during the Eighty Years War involved creative exploitation of terrain, in this case flooding the land surrounding Leiden (inundation tactics) (p. 37) to force invading Spanish forces to retreat. Chapter Three looks at the foundations of British Amphibious Doctrine during the Seven Years War (1756-63). Here, Andrew Young, a former Royal Navy officer engaged in doctoral studies in naval history at King's College London, recounts the role of Thomas More Molyneux in formulating amphibious doctrine with emphasis on his 1759 text Conjunct Expeditions (p. 39). The main lesson extracted from this chapter is the importance of sea control in enabling littoral maneuver. Without at least total local command of the sea the ability to "launch, sustain, or recover operations ashore" (p. 53) is compromised.

The Delaware River Campaign of 1777 by historian James R. McIntyre is the topic of Chapter Four, which looks at 18th Century amphibious operations during the Revolutionary War. This campaign demonstrated the importance of what we now call "jointness" or unity of effort between naval and land forces with the application of unified command augmented by institutionalized amphibious experience (pp. 71-72). The British ultimately won the campaign due to these factors. The one exceptionwhich helps prove the value of unified command and operations-was seen in the attack on Fort Mercer where the basic principles of joint operations were ignored. Once those precepts were reestablished the British went on to win the campaign.

Vera Cruz, 1847 is the case study examined by J. Overton, a U.S. Navy civilian who served as an adjunct professor at the Naval War College and Marine Command and Staff College, in Chapter Five. The MexicanAmerican War provides the backdrop for this landing. The operation (Battle of Veracruz) involved a siege of Veracruz, a seaport city, under the overall command of Major General Winfield Scott. Navy Commodores David E. Conner and later Matthew C. Perry U.S. Navy operations. Vera Cruz demonstrated the importance of a solid command understanding of operational factors: time, forces, and space (p. 82).

In Chapter Six, "Courting Disaster," Edward J. Hagerty, a historian who served with the U.S. Air Force, recounts the Civil War Battle of Santa Rosa Island (1861). Here confusion, a complete lack of mission training for 
amphibious operations, and lack of hydrological knowledge and intelligence preparation denied the Confederate attackers under Brigadier General Braxton Bragg victory. Bragg's desire for action skewed his risk/benefit analysis and poor planning led to his loss (pp. 104-105).

The importance of operational alignment with strategic goals is the lesson of Chapter Seven on U.S. Navy and Marine Corps support of great power competition in late $19^{\text {th }}$ Century Korea. In this case, Benjamin Armstrong, a naval officer and history professor at Annapolis and author of Small Boats and Daring Men: Maritime Raiding, Irregular Warfare, and the Early American Navy, ${ }^{6}$ reminds the reader that tactical prowess and victory does not ensure strategic success. Amphibious operations must align with operational and strategic possibilities (p.124). Eric A. Sibil, an historian who served at the NATO Baltic College, assesses Estonian amphibious operations in the Baltic during the Estonian War of Independence (1918-20) in Chapter Eight. He points out that amphibious operations enhanced Estonian maneuver and allowed them to employ surprise and engage Bolshevik and German forces in unexpected places (pp. 125-146). Leadership and organizational skills were imperative and outweighed the lack of extensive naval experience, although extensive maritime skills and seamanship combined with flexibility were instrumental in achieving operational success (p. 146).

Chapter Nine by Angus Murray, a doctoral student at the University of Newcastle reviews the importance of Gallipoli7 on interwar U.S. Marine Corps planning and doctrinal development. The U.S. Navy and Marines used the interwar period to develop and exercise (and thus hone) new amphibious skills. These efforts were instrumental in developing the framework for amphibious operations in War Plan Orange (the strategy for naval engagement that was realized in World War II in the Pacific. Essentially study of Gallipoli-and its failures--underscored USMC efforts to develop meaningful amphibious capabilities and doctrine. General Holland Smith acknowledged the importance of these efforts, including Landing Operations Doctrine, ${ }^{8}$ that carried the Marines through "Tarawa, Normandy, and Iwo Jima (p. 165). 9 


\section{Case Studies: Chapters Ten-Seventeen}

Chapters Ten-Seventeen review amphibious operations during World War II, with an additional examination of the lesser-known application of amphibious operation almost three decades after that war by the Turks in Cyprus (1974).

"Ambiguous Application: The Study of Amphibious Warfare in Marine Corps Schools" by Bruce Gudmundson, who was educated at Oxford and Parris Island, provided a unique insight into the development of doctrine and professional thinking of amphibious operations and tactics leading up to World War II and the Pacific Campaign in Chapter Ten. Chapter Eleven, "Operation Weserubung: Early Amphibious Multidomain Operations" by James K. Greer, an assistant professor at the school of Advanced Military Studies, discussed early amphibious multidomain operations in Norway. While the Norway campaign is not generally studied as closely as other amphibious operations, it does present a unique window into modern (post-WWI) doctrinal change in that the German's integrated from planning through execution a combined arms approach with air, sea and land forces providing multi-domain "synergy" of mutually supporting efforts.

Chapter Twelve, "The Reich Strikes Back: German Victory in the Dodecanese, October-November 1943" by historian and political scientist Jeffrey Schultz reveals that through superior application of amphibious art, a strategically crippled Germany, losing on multiple fronts, was able to thwart a British takeover of the Aegean in the wake of Italy's surrender to allied forces. While a relatively expensive effort for the Germans, for arguably minor strategic gain, the Germans were able to leverage shorter supply routes and an existing regional military presence that proved decisive in defeating a less organized and largely dispersed British effort to take these islands. It also demonstrated the German Navy's ability to wage amphibious warfare under disputed conditions. A well-executed amphibious operation, even in context of other major setbacks across the theater, can prove operationally successful with the right planning and amalgamation of forces and tactics.

"Missing the Mark: Naval Gunfire Lessons from Tarawa," Chapter Thirteen by James P. McGrath III, an adjunct professor at the Naval War 
College documents the stark lessons learned at Tarawa where Navy planners overpromised the effects of Naval gunfire without due regard to Japanese preparations to mitigate that threat. In short, Naval Gunfire underdelivered. While destroyers offshore provided some exemplary direct fire support of Marine maneuver forces once ashore, proving the potential value of this support while in contact with the enemy, the preparatory fires were inadequate to achieve the operational advantage desired prior to landings and the author does a good job explaining how this altered thinking formed from interwar years, especially the Marine Corps "Tentative Manual for Amphibious Operations" of 1934. While the price was high, Tarawa did deliver profound lessons learned that were applied in follow-on operations, although the success of Tarawa was summed up by General Julian Smith, "We made fewer mistakes than the [Japanese] did (p. 239)."10

"Soviet Strategic Attack and Tactical Amphibious Failure in the Merkula in 1941," Chapter Fourteen by Andre Del Guadio, a retired Marine infantry officer, reinforces the need close coordination of air, sea, and land forces, and why such operations must be rehearsed at all echelons to ensure successful amphibious operations. The chapter outlines how the Soviets rushed into this this most difficult of military operations, believing the tactical advantage before them somehow overcame the need for proper preparation and coordination, and they paid a huge price for the ensuing failure. Merkula went from a being a strategic opportunity, to the Soviets to devolving into an "operational diversion to be dealt with harshly at the water's edge by the Germans (p. 252).”

"Learning the Lessons of Port-en-Bessin, 1944," Chapter Fifteen by John D. Salt, a lecturer at Cranfield University, is a testament to the superior quality of British Marine Royal Marine Commandos compared to their German counterparts, and that this played a critical role in overcoming a series of operational setbacks that would have likely discouraged lesser capable, disciplined, and well led military forces.

Chapter Sixteen, "German Naval Evacuations of the Eastern Front, 194445 " by Gregory Liedtke, a historian specializing in German military history, provides a review of a lesser-known amphibious evacuation of German forces on the Eastern Front, in Crimea. It points to the larger strategic problem of Hitler's reluctance to withdraw forces, pushing the 
German $17^{\text {th }}$ Army into a position where there was no other option but to withdraw via the sea. Despite heavy losses, the operation was considered a success. It also points to the role that the Romanian Navy played with the German Navy in enabling this success. Of note, pockets of German forces supplied by the sea tied up much larger Soviet forces until nearly the end of the war, making this a remarkable story about economy of force actions, and the importance of amphibious support to forces cut off from ground supply lines.

"Against All Odds: Turkish Amphibious Operation in Cyprus, 20-23 July 1974," Chapter Seventeen by Turkish scholars Serhat Guveng and Menut Uyar recounts a poorly planned and executed amphibious operation that has all the hallmarks of a tactical failure even though it is generally seen as successful operationally. The chapter explores the history and respective orders of battle between the opposing forces in Cyprus, and particularly the political dynamics surrounding this operation. What makes this so remarkable is that both sides (Greece and Turkey) are NATO members, and that this action did not result in either leaving NATO or having to leave NATO. It also points to the fact that the Turks had no real experience in conducting amphibious operations prior to 1974 , and that it was arguably the most complex campaign ever conducted by Turkish armed forces anywhere.

\section{The Future: Chapters Eighteen-Twenty-Three}

Chapters Eighteen-Twenty-Three peer into the future of amphibious operations to discern the need for critical doctrinal changes. The Role of Amphibious Operations within the Multidomain Operational Construct Background and Considerations," Chapter Eighteen by Keith D. Dickson, a professor at the National Defense University, discusses the transition to Multidomain Operational (MDO) doctrine from what had previous been called Air-Sea Battle. It draws from Joint Operating Environment 2035, wherein future confrontation will be part of "antagonistic geopolitical balancing" (p. 331). It proclaims that, "MDO outlines an agile force reacting responding, initiating, aggregating, and disaggregating and capable of multidomain convergence, all without loss of momentum" ( $\mathrm{p}$. 328). 
"The Future is Amphibious: The Role of Naval Special Warfare in the Great Power Competition," Chapter Nineteen by Shulakshana Komerath, at the Office of the Secretary of Defense, encapsulates an ongoing discussion within the Naval Special Warfare community as it transitions from two decades of counterterrorism (e.g., ground conflict) to providing critical support in conflict and confrontation with near-peer competitors. Figure 6.7 on page 333 provides a very simple but powerful example of this transition of skillsets and missions from the ground to the maritime domains, but also the unique "amphibious" zone where they overlap, and an area where this new era of great power competition is likely to see more utilization of the Naval Special Warfare capabilities being applied. It also mentions the need for a more "holistic approach to intelligence gathering, maintaining awareness of the battlespace, and keeping military as well as well as political and economic tools available to manage the GPC [Great Power Competition] rivalry" (p. 338-9).

"Uncertainty, Maskirovka, and Militarism: Russian Perspectives and Amphibious Assault Potential in the Arctic Near Future," Chapter Twenty by Ellen A. Allness, an Arctic military affairs specialist, explores Russia's changing Arctic capabilities and intentions. The Arctic has the potential to become a flashpoint due to lack of surveillance capabilities in the region. In short, it is too far north. Meaning that practicing deception in this region is very easy, making strategic surprise more likely. Chapter Twenty-One, "Naval Strategy and the Future of Amphibious Operations, by B.A. Friedman lays out the fundamental challenges to conducting amphibious operations in today's precision long-range munitions environment, with the detrimental impact this has on classic amphibious force landings, but it also lays out the increasing role for other kinds of amphibious operations to counter this threat, such as raids.

"The United Kingdom's Approach to Amphibious Operations: From the Cold War to the Information Age," Chapter Twenty-Two by Kevin Rowlands, a Royal Navy Captain, explains how the UK's approach to amphibious operations has changed, much of that due to a lack of amphibious shipping needed for large-scale force projection ashore. Modern amphibious forces may be smaller but more specialized, focused on the challenging mission of maritime area denial. While they adhere to NATO doctrine (p. 371), they can also deliver "lasting effects whether in acting in conflict, capability building, or humanitarian assistance" (p. 371). 
Chapter Twenty-Three, "The Marine Corps and Advanced Base Operations: Past, Present and Future" by Marine infantry officer Walker D. Mills provides a detailed analysis of seizing advanced naval bases. It explores the past, present, and future of advanced bases and the importance of anti-access/area denial (A2/AD) (p. 385) networks in the various oceans and seas worldwide, emphasizing that land-based missiles ore a critical component of Chinese A2/AD strategy.

\section{Conclusion}

In their conclusion, Freidman and Heck remind us that amphibious warfare is characterized by both continuity and change. At its core, it involved the projection of combat power from the sea to the shore (p. 393). As the entirety of their edited collection confirms, amphibious operations are more than amphibious assaults. They include a range of littoral operations, including raids, special operations, humanitarian support actions, and yes: large scale amphibious assaults. From the Peloponnesian War (and likely before) to the present, amphibious operations allowed rivals to project military force from the sea to shore. ${ }^{11}$ Sea power was an integral component of classical Mediterranean wars. As John Nash, an Australian naval officer and classical scholar noted, sea power in the Peloponnesian war spanned the full spectrum of maritime operations. These include what is known categorized in Australian maritime doctrine as military, diplomatic, and constabulary (policing operations). ${ }^{12}$

As Sulakshana Komerath noted in Chapter Nineteen, contemporary naval special warfare capabilities embrace amphibious operations to achieve special reconnaissance, infiltration/exfiltration, clandestine intelligence collection, amphibious assault, and sabotage operations (p. 333). As B.A. Freidman reminded us in Chapter Twenty-One, this involves the "return of the raid or "Guerre de Razzia" (p. 359-362). The future of amphibious operations will be complicated by the urban littoral where urban warfare and littoral operations in a contested environment (LOCE) converge. ${ }^{13}$ As Dayton McCarthy noted in his Australian Army Occasional Paper, the urban littoral is "the worst of both worlds." 14 In addition, robotic warfare (ghost fleets), ${ }^{15}$ drones, (aerial unmanned aerial systems-UAS, unmanned surface vessels-USV, unmanned underwater vessels-UUV, and unmanned ground vehicles-UGV), along with artificial intelligence (AI), 
AI-enabled sensors, pulsing and swarms will both complicate the environment and bring new capabilities to both offensive and defensive forces. ${ }^{16}$ All of these will require concerted efforts to explore new approaches through wargaming and development of robust intelligence capabilities. ${ }^{17}$

As a compendium of smaller works, the text provides a broad overview of many different topics tied to history, strategy, operations, tactics, doctrine, and major changes in amphibious operations. It also provides a view that looks well beyond other more U.S.-centric works, and while it addresses many of the more well-known amphibious operations, it tends to focus on those particular operations that provide key doctrinal lessons or where those operations proved to be a strategic inflection point in how strategy and tactics suddenly shifted thereafter. For any serious student of amphibious warfare this book is an invaluable reference guide. On Contested Shores is a valuable contribution to the naval and military literature on amphibious warfare and operations. Strategists will also benefit from its lessons as they consider future maritime and amphibious operations. Hopefully, this collection will stimulate new discussion and doctrinal development for the amphibious operations of the future.

\section{Endnotes}

1 Commandant David Berger articulated a new (renewed) vison of the United States Marine Corps (USMC) emphasizing the Fleet Marine Force and integration with the United States Navy (USN) notably returning the USMC to its maritime and amphibious roots and calibrating force structure to embrace partnership with the USN to enhance capabilities for Littoral Operations in a Contested Environment (LOCE) and Expeditionary Advanced Base Operations (EABO). See David H. Berger, Commandant's Planning Guidance: $38^{\text {th }}$ Commandant of the Marine Corps. (Washington, DC: United States Marine Corps, Headquarters Marine Corps, 2019) and Force Design 2030. (Washington, DC: United States Marine Corps, Headquarters Marine Corps, March 2020).

2 The Royal Marines (RM) are also emphasizing amphibious operations, in their Littoral Strike concepts and transition into a 'Future Commando Force' (FCF). See Gavin Cordon, "Royal Marines to form new commando force in armed forces shake-up." Evening Standard. March 22, 2021, https://www.standard.co.uk/news/uk/royalmarines-ben-wallace-army-defence-ministry-of-defence-b925440.html and Megan Eckstein, "NATO Maritime Commander: Allies Are Coming Up With Modern Littoral Warfare Concepts, and NATO Needs to Exercise Them." USNI News (U.S. Naval Institute). May 20, 2021, https://news.usni.org/2021/o5/20/nato-maritimecommander-allies-are-coming-up-with-modern-littoral-warfare-concepts-and-natoneeds-to-exercise-them.

3 David Lague, "China expands its amphibious forces in challenge to U.S. supremacy beyond Asia." Reuters. July 20, 2020, https://www.reuters.com/investigates/special- 
report/china-military-amphibious/ and Kerry K. Gershaneck, "China's amphibious ambitions emerge in South China Sea." Asia Times. May 31, 2018,

https://asiatimes.com/2018/05/chinas-amphibious-ambitions-emerge-in-southchina-sea/.

4 See, for example, William L. McKee, Amphibious Operations in the South Pacific in World War II. (Santa Barbara: BMC Publications (3 Volumes), 2000-2009).

5 The U.S. invasion at the Port of Inchon (Inch'ŏn) or Operation Chromite, an amphibious landing 15-26 September 1950 reversed the course of the Korean War in favor of the United States, South Korean, and Allied Forces (including the Royal Navy). The operation under the command of General of the Army Douglas A. MacArthur, the U.S. Commander in Chief, Far East and Commander in Chief, United Nations Command (CINCUNC) involved coordinated sea, air, and land operations demonstrated the decisive potentials of amphibious (and naval) operations in littoral operations. See Curtis A. Utz, Assault from the Sea: The Amphibious Landing at Inchon. (Washington, DC: Naval History and Heritage Command. Department of the Navy. 2020), https://www.history.navy.mil/content/dam/nhhc/research/publications/PublicationPDF/Assault\%2ofrom\%20Sea\%20508.pdf.

6 Benjamin Armstrong, Small Boats and Daring Men: Maritime Raiding, Irregular Warfare, and the Early American Navy. (Norman, OK: University of Oklahoma Press, 2019).

7 On the political impact of Gallipoli and the Dardanelles Campaign see Chapter 15, "Isolation and Escape: in Martin Gilbert, Churchill: A Life. (New York: Henry Hilt and Company), 1991, pp. 310-329;

8 Landing Operations Doctrine, FTP 167, (Washington, DC: Division of Fleet Training, Office of Naval Operations, 1938).

9 Gen. Holland M. Smith and Percy Finch, Coral and Brass. (New York: Curtis Publishing, 1949).

${ }^{10}$ Col. Joseph H. Alexander, Across the Reef: The Marine Assault of Tarawa. (Washington, DC: History and Museums Division, Headquarters Marine Corps, 1993), pp. 6-7.

${ }^{11}$ Thucydides chronicled that conflict between Athens and Sparta. See Robert B. Strassler, Ed. The Landmark Thucydides: A Comprehensive Guide to the Peloponnesian War. (New York: Simon \& Schuster, 2008).

${ }^{12}$ John Nash, "Sea Power in the Peloponnesian War." Naval War College Review. Vol 71, no, 1, Winter 2018, https://digitalcommons.usnwc.edu/cgi/viewcontent.cgi?article $=1007 \&$ context $=$ nwc-review. Nash cited Ken Booth, Navies and Foreign Policy (Lon-don: Croom Helm, 1977), p. 16; Eric Grove, The Future of Sea Power (London: Routledge, 1990), p. 234; and Royal Australian Navy, Australian Maritime Doctrine (Canberra: Sea Power CentreAustralia, 2010), p. 100.

13 See Dave Dilegge, Robert J. Bunker, John P. Sullivan, and Alma Keshavarz, Eds. Blood and Concrete: 21st Century Conflict in Urban Centers and Megacities. (A Small Wars Journal Anthology.) (Bloomington, Xlibris, 2019) and David Kilcullen, Out of the Mountains: The Coming Age of the Urban Guerrilla. (Oxford and New York: Oxford University Press, 2013).

14 Dayton McCarthy, "The worst of both worlds: An analysis of urban littoral combat." Australian Army Occasional Paper, Conflict Theory and Strategy 002. (Canberra: Australian Army Research Centre, April 2018), https://researchcentre.army.gov.au/sites/default/files/the_worst_of_both_worlds.pdf

15 See P.W, Singer and August Cole, Ghost Fleet: A Novel of the Next World. (Boston and New York: Mariner Books, 2015) for a FICINT (fictional intelligence) scenario of future naval warfare.

${ }^{16}$ On swarming and pulsing, see John Arquilla and David Ronfeldt, Swarming and the Future of Conflict. (Santa Monica: RAND, 2000), https://www.rand.org/pubs/documented_briefings/DB311.html. 
${ }^{17}$ Hal Kempfer and John P. Sullivan, "Connecting Partnerships for the Co-Production of Full-Spectrum Threat Intelligence. CIMSEC (Center for International Maritime Security). April 2, 2021, https://cimsec.org/connecting-partnerships-for-the-coproduction-of-full-spectrum-threat-intelligence/. 